\title{
Makale ve Günlüklerinden Hareketle Ömer Seyfettin'in Görüşleri Üzerine Bir Değerlendirme
}

\author{
Murat TURNA*
}

$\ddot{\mathbf{O} z}$

Ömer Seyfettin Türk kültür ve edebiyat hayatında genellikle hikâyeleri ile bilinir. Oysa fikra, makale, çeviri, mektup, günlük ve şiir türlerinde de eserler ortaya koymuş bir sanatçıdır. Yazdığı türler arasında hayata bakışını, ideallerini ve kaygılarını, samimi ve ayrıntılı hâliyle yansıtanlar ise fikra ve makaleleridir. $\mathrm{Bu}$ yazılarda, mahut hikâye yazarı kimliğinin ötesi bulunur. Nitekim hikâyelerinde işlediği temaların fikrî nüveleri de en net, en yalın hâliyle fikra ve makalelerindedir. Esasen Türk fikir hayatına bir aydın olarak birikimini, ileriye dönük arzu ve çekincelerini en kuvvetli şekliyle fikra ve makaleleri ile aktarmıştır denebilir. Ömer Seyfettin'in görüşleri, kendi devrinde günün konusu olmuş ve polemikler doğurmuştur. Sanatçının ortaya koyduğu fikirlerin hâlen aktüel olması kayda değerdir. Bu makale, Ömer Seyfettin'in bir asır önce ifade ettiklerinin, bugün için bir anlam taşıyıp taşımadığını araştırmak üzere kaleme alınmıştır. Araştırmanın temeli, sanatçının fikirlerinin yoğunlaştığı fikra ve makalelerine dayanır. Bunların yanı sıra günlüklerinden de faydalanılacaktır. Bu yazıları esas alınarak Ömer Seyfettin'in görüşlerinden hangilerinin bugüne intikal edebildiği, bunların ne derecede önemini koruduğu; kısaca Ömer Seyfettin'in bugüne neler söylediği irdelenecektir.

Anahtar Kelimeler: Ömer Seyfettin, Makale, Türklük, Türkçe, Siyaset.

* Dr. Öğretim Üyesi, Necmettin Erbakan Üniversitesi, Ahmet Keleşoğlu Eğitim Fakültesi, Türkçe Eğitimi Bölümü, Konya, Türkiye,

Elmek: mturna@erbakan.edu.tr,

https://orcid.org/0000-0002-1413-6246.

Geliş Tarihi / Received Date: 04.06 .2020

Kabul Tarihi / Accepted Date: 09.10.2020 


\title{
An Evaluation of Ömer Seyfettin's Views Based on his Articles and Diaries
}

\begin{abstract}
Ömer Seyfettin is generally known for his stories in Turkish cultural and literary life. However, he is an artist who has also created works in columns, articles, translations, letters, diaries and poetry. Nevertheless among the genres he wrote, those who reflect his views on life, his ideals and concerns in a sincere and detailed manner are his columns and articles. In this writings he is beyond the identity of known narrator. As a matter of fact the intellectual cores of the themes he studied in the stories arein his columns and articles in a clearest and the simplest form. Essentially it can be said that as an intellectual he conveyed his repertoire, forwardlooking wishes and reservations in the most powerful form via his columns and articles to Turkish intellectual life.

Ömer Seyfettin's views were the subject of his time and led up to polemics. It is noteworthy that the ideas presented by the artist are still current. This article has written to find out whether Ömer Seyfettin expressed a century ago has any significance for today or not. The basis of the research is based on the columns and articles of the artist's ideas. In addition his diaries will also be used. On the basis of these writings which of the views of Ömer Seyfettin transferred to today and to what extent they maintain their importance and what Ömer Seyfettin said about today will be examined.
\end{abstract}

Keywords: Ömer Seyfettin, Article, Turkishness, Turkish, Politics. 


\section{Extended Summary}

Ömer Seyfettin is known by many as a story writer. However, he also has many articles. His articles provide information about the origins of his theses in his stories. These articles explain the views of the artist. Thought enlightens your life. It also explains what issues the Turkish society was considering a century ago. The writings of the intellectuals shed light on the lives of societies. It presents the problems that Ömer Seyfettin wrote a century ago, experienced in the 19th century Ottoman geography. According to this, the Ottoman Empire is going through a difficult process. There is a social unity about to break up. Ömer Seyfettin struggles to prevent this breakup. Ideas suggest. In this study, the theses put forward by the artist will be examined. From his perspective, the concept of nation is concentrated. National ideals are considered. In this context, the meanings of what Ömer Seyfettin said for today are important. The degree of permanence and consistency of the artist's views is thus revealed.

Ömer Seyfettin is also a soldier. Apart from his writing, he also has military experience. He is an intellectual who fought against enemies, chased bandits in the mountains, defended his state. The background of his writings has his own personal experience. Social and political instability of his period should also be added. The 19th century has deeply influenced Turkish intellectuals and artists. This period is a very important period for the Ottoman. Because the political and social developments in this period shook everyone. Homeland has been lost. Political integrity has been lost. The economy has deteriorated. The people experienced morale as morale. Intellectuals and artists felt responsible for addressing the problems of society. Ömer Seyfettin is such a responsible intellectual. He witnesses Turks losing their land in Europe. It sees the casualties experienced on the spot. Therefore, he persistently defends the ideal of nationalism after the Balkan Wars. This was previously a cultural nationalism. Later, its political aspect becomes evident. In the articles written by Ömer Seyfettin, how nationalism is handled constitutes a certain aspect of this study.

It should be noted that the issues mentioned by an artist who has experienced important breaking moments of history such as Ömer Seyfettin and 
the lessons he learned are also relevant today. Another subject that he emphasizes is Turkish. Turkish is a key instrument in the artist's ideas. Language is an element that provides unity. It will be thanks to the language that the people are educated and gathered together by gaining awareness. Therefore, plain and understandable Turkish is important. It should be noted that this view of Ömer Seyfettin is accurate. He advocated an opinion that surpasses the age and concerns the present.

Ömer Seyfettin deals with very different topics in his articles. Military service, economy, secret organizations are also subject in his writings. It especially draws attention to some organizations that have a sneaky place in the society. He is against organizations like freemasonry. He thinks that Freemasonry harms national integrity. He thinks that non-governmental organizations should be transparent.

Freedom of thought is another issue it deals with. He criticizes the lack of respect for thoughts. He complains about this situation. Ömer Seyfettin attributes the reasons of the social backwardness to the main articles such as the blindly imitating the West, moral disorders and political mistakes. Especially the moral defeat in the society disturbs him very much. Ömer Seyfettin pays special attention to the education of women, children and youth on the path of community development. It refers to the role of sport in mind and body training. It is observed in his writings that gymnastics passes a lot. He argues that he should be a national side in sports. He notes that national gymnastics is wrestling, horse riding, running, swimming, shooting and gives details on how to do these sports.

Ömer Seyfettin is a 20th century intellectual. Russian, British and French threats, Balkan defeat, the risk of provoking Armenians and Kurds against the Turks, the activities of secret societies, various strategic ideas, fear of occupation of Anatolia are discussed in the writings of Ömer Seyfettin. In other words, the themes that hold a wide place in Ömer Seyfettin's jokes and articles still maintain their current status because the dangers and anxieties towards the national existence are the same. This can be explained primarily by geopolitical position. Attention was drawn to the policies of the artist, both as a soldier and as an intellectual. It is necessary to analyze the cause of the disasters well. Europe is an exemplary enemy. It proceeds to its goal with its politics, institutions, insidious ambitions and long-term plans. All these voices were evaluated in terms of permanence and consistency in the context of this study, considering today's facts. 


\section{Giriş}

Ömer Seyfettin'in (1884 - 1920) sayısı yüzlerle ifade edilen fikra ve makaleleri onun ideolojisini, geleceğe dair öngörü ve ikazlarını içermesi itibariyle dikkate şayandır. ${ }^{1} \mathrm{Bu}$ yazılarda dönemini tahlil eden, ağırbaşlı ve mustarip bir aydın belirir. Konu bakımından çeşitlilik arz eden yazılarında sanatçı, Amerika'daki zenci esirlerin azadından Türkçe dil kaidelerine, kadın eğitiminden Milletler Cemiyeti'ne üye olmaya dek okuyucularına oldukça geniş bir fikir yelpazesi sunar. Jimnastikten siyasi meselelere, yazma tavsiyelerinden sosyal eleştiriye pek çok konuda makale kaleme almıştır. Onun makalelerinde (ve fikralarında) yer alan görüşleri üç başlık altında incelenecektir. İlki Türklük, millet kavramı, millî idealler üzerine yazdıklarıdır. İkincisi Türkçe, dil bilinci, dilin sosyal fonksiyonu hakkındaki fikirleridir. Üçüncüsü ise diğer meseleler başlığı altında ele alınacak olan vatan sevgisi, ordu ve eğitim üzerine dile getirdikleridir.

Bunlara dâhil edilemeyecek ancak önemi ve etkisi dolayısıyla ihmal edilmemesi gerekenlere de ayrı bir başlık altında olmasa bile, ayrı bir ya da birkaç paragrafta değinilmesi zaruridir; çünkü bunlar müstakil bir başlık altında işlenecek yoğunlukta olmamakla beraber, temas edilmeden geçilmesi uygun düşmeyecek hususlardır. O yüzden masonluk, gizli cemiyetler, fikir hürriyeti spor gibi hususlara da üçüncü başlığın altında kısaca değinilecektir.

Ömer Seyfettin'in yazıları, bugünün okurları ve aydınları için önemlidir. Tarih ve sanatın zaman zaman yakınlaştığı; tarihî ve millî bilincin, aydınların yazdıklarıyla bugünün kuşaklarına aktarıldığı hatırda tutulmalıdır. (Değirmenci 2014: 17) O yüzden Trablusgarp, Balkan Savaşları, I. Dünya Savaşı, Çanakkale ve topyekûn kurtuluş mücadelesi gibi Türk tarihinin önemli kırılma anlarını yaşamış Ömer Seyfettin'in bahsettiği hususların ve çıkarttığı derslerin bugünü de ilgilendirdiği kaydedilmelidir. En mühimi de o, Komanova'da Sırplara, Yanya'da ise Yunanlılara

1 Nazım Hikmet Polat'in ilk elden vesikalara dayanarak ortaya koyduğu Ömer Seyfettin - Bütün Nesirleri isimli eser, araştırmanın temel kaynağıdır. Makale, büyük oranda, kaynakçada da belirtilmiş olan bu kitaba dayanır. Buna göre sanatçının tespit edilmiş fikra ve makale yazısı toplamı 216'dır. (Bu makalede mezkûr yazıların yanı sıra toplam 15 mektubu, "Balkan Harbi Hatıraları" ve "Ruzname”si de göz önünde bulundurulmuştur.) 
karşı bizzat savaşmış, esir düşmüş; Naflion'daki esaretinin ardından 1913'te memleketine dönebilmiştir (Ömer Seyfettin 2015: 17). Bu da Ömer Seyfettin'i Türk aydınları ve sanatçıları arasında ayrıcalıklı bir yere koymaktadır; zira cephe gerçeklerini öğrenmiş ve acı tecrübeleri olan bir kimsedir. Yazılarındaki görüşleri kendi hayatından, yaşadığı dönemdeki somut örnek ve hadiselerden beslenir.

\section{Türklük - Millet Kavramı - Millî İdealler}

Ömer Seyfettin'in Türklük hususunda söyledikleri, çok yakından tanıdığı Ziya Gökalp ile aynı doğrultudadır. Gökalp çağdaşlarını etkilemiş bir düşünürdür. Onun sisteme döktüğü “terminolojik ve fikrî yapı” Ömer Seyfettin tarafından takip edilir. (Çalen 2015: 154). O da Ziya Gökalp gibi meselenin ırk kavramı üstünden tartışılmasını istemez. Onlara göre milliyeti tespitte, saf kan aranması beyhudedir. Türklük, bir ırk saplantısı değildir ve olmamalıdır. Ömer Seyfettin'in bu konudaki görüşleri yanlış anlamaya yer bırakmayacak kadar açıktır:

“Bugün milletlerde urk esası aramak 'elkimya' ile meşgul olmaktan ziyade gülünçtür... Dünyanın hangi dershanesine gitseniz ırk nazariyesinin reddedildiğini görürsünüz. Hiçbir yerde saf bir ırk kalmamıştır. Fakat milletler vardır. Milletler de lisan, terbiye, maarif ve din gibi vahdetlerin topladı̆̆ mecmualardır... O hâlde biz de Türk derken ırk ve kan cihetlerini derin derin araştırmamallyız." (Ömer Seyfettin, 2018: 435 - 437).*

Yazar "Milliyet Aleyhtarlığı” başlıklı yazısında, bu konuya eğilirken, milliyetin hiçbir surette ırk demek olmadığını yineler ve meseleyi şöyle açıklığa kavuşturur:

“Milliyet nedir? Işste bugün belki beş yüzüncü defa tekrar söylüyorum:

- Milliyet, ırk demek değildir. Dünyada saf ırk kalmamıştır. Muharebeler, muhaceret devirleri ırkları karıştırmıştır. Yalnız Fransa'da altmışı mütecaviz ırkın etnik izleri vardır. Milliyet 'Lisanca, dince, harsça, hissiyatça birbirine benzeyen insanlar mecmûuna'derler. Ayrı ayrı siyasî idareler altında yaşasalar da dini, dili, harsı bir olan millet ayrı bir millet sayılamaz." (569).

\footnotetext{
* Makale boyunca Ömer Seyfettin'in yazılarından yapılacak olan alıntılarda kaynak olarak "Ömer Seyfettin. (2018). Bütün Nesirleri, (Haz. : Nazım Hikmet Polat) Türk Dil Kurumu Yayınları, Ankara.” kullanılacaktır. Bundan sonra bu kaynağa ait göndermelerde sadece sayfa numarası gösterilecektir.
} 
“Milliyet kanda değil, candadır” diye düşünen Ömer Seyfettin (569), bazı aydınların konuyu kavrayamadıklarından şikâyetçidir. Irkı milliyet, milliyeti ırk zanneden kimi okumuşlara tepki göstererek ırkın "mevhume", milliyetin ise "hakikat" olduğunu belirtir. Milliyetin sınırı dil ve kültürdür. Ona göre Türkçe konuşup yazan, Türk terbiyesinden nasip alan, Türk milletinin ideallerini ve hissiyatını paylaşan her Müslüman, "halis muhlis Türk’tür”. Bu görüşlerini kanıtlamak istediği "Mefhum Buhranı" yazısında, insanın köken itibariyle başka bir milliyete mensup olmasının da hiçbir önemi olmadığını ileri sürerek bir dostunu, savunduğu görüşe örnek olarak verir. Fransız İhtilali esnasında Türkiye'ye kaçıp Müslüman olan bir Fransız'ın artık üçüncü kuşağı olan dostu, aslında “Türkleşmiş bir Fransız asilzadesi”dir. Hatta gayet meşhur da bir konttur ancak bu kişi tek kelime dahi Fransızca bilmemektedir. Ruh ve his bakımından Anadolu insanından farkı yoktur. Bu durumda kalkıp onu uzak cetlerine nispetle Fransız ilan etmek, Türk olmadığını beyan etmek "hilaf-ı hakikat”tir. Ömer Seyfettin Türkiye'de doğan veya buraya yerleşen yahut Türklüğü ruhunda duyan ve cetlerinin milliyetine dönmeyip fiilen Türkleşen tüm Müslümanları Türk kabul eder. ( 790 - 791).

Sanatçı bu doğrultuda millet kavramını da tanımlar. Millet aynı dini, dili, terbiyeyi benimseyen, bu ögelerle birbirine bağlı olan insan topluluğudur. Görüşlerini özetleyip neredeyse formül hâline soktuğu aşağıdaki satırlar, Ömer Seyfettin'in bu konularda zihninin ne denli berrak olduğunu ve kavramları nasıl kolayca birbirinden ayırdığını gösterir:

"Dinleri bir olmakla beraber lisanlarl da bir olan bütün insanlara 'millet' adl verilir.

Türkçe konuşan bütün Müslümanlar Türk milletindendirler.

Demek, milliyet 'din ve dil' birliği olan bir halkın adıdir... Millet, ümmet, devlet... Bu üç kelimenin mânalarını açıkça bilmelisiniz. İşte yazıyorum, dikkat ediniz ve aklınızda tutunuz:

Millet: Bir lisanla konuşan fakat dinleri bir olan bütün insanlar...

Ümmet: Ayrı ayrı lisanlarla konuşan fakat dinleri bir olan bütün insanlar...

Devlet: Lisanları ve dinleri, yani ümmetleri ve milletleri ayrı ayrı olan insanları bir toprakta idare eden müessesedir. 
Biz Türk milletinin, İslâm ümmetinin, Osmanl Devletinin fertleriyiz." ( 461).

Mamafih yazarın görüşleri bir de bugünün gerçekleri ile kritik edilmelidir.

Günümüzde Türkçe konuşan ve Müslüman olan ancak milletinin ideallerini, hissiyatını paylaşmayan fakat sanatçının çizdiği çerçeveye göre Türk telakki edilebilecek kimseler mevcuttur. Bunun yanında gerek Türkiye sınırları içinde gerekse sınırların dışında Türkçe konuşan hatta daha da ilerisi, Türkçülük ideolojisini benimseyen ancak "ehl-i İslâm" olmayan kimseler de bulunur. ${ }^{2}$ Ömer Seyfettin'in anlayışına göre bu gibi kimseleri Türklüğün dışında saymak lazımdır ki bu da fikren bir çelişkiyi beraberinde getirir. Ayrıca onun çerçevesini çizdiği Türklüğün içine Gagavuz Türklerini ve Yakut Türklerini de katmamak icap eder. Konuşmaları açık bir şekilde Türkiye Türklerince de anlaşılan Hristiyan Gagavuz Türkleri ve daha kuzeyde kalan Yakut Türkleri, Türklüğün kapsamı dışında kalmaktadır. Gagavuz ve Yakut Türklerini Türk kabul etmeyişin, Ömer Seyfettin'deki Türk birliği düşüncesiyle bağdaşmadığı aşikârdır.

Dağılan muazzam bir siyasi yapının kurtuluşu için İslamcılık, Osmanlıcılık, Türkçülük gibi fikir akımlarının öne çıktığı çalkantılı bir devirde, Ömer Seyfettin'in düşündüklerini teorik bir düzleme aktarma gayreti saygıdeğerdir. 1910'larda dile getirdiği millet kavramının o günün koşullarınca gayet net olduğu kabul edilmelidir. Ne var ki zihni bu konularda epey yorulmuş olan sanatçının görüşlerini, bugünün koşullarıyla ya da gerçekleriyle revize etmek şarttır. Onun Türk olmanın, millet olmanın vazgeçilmez unsuru addettiği dinin, sunduğu formüldeki yeri, bugün tartışmaya açıktır. Ömer Seyfettin'in bir asır önceki Türklük tanımı, günümüz sanatçılarından İsmet Özel'in Türklük kavrayışını da akla getirir. Türk kavramını tanımlayıcı kültürel figürler olmaları nedeniyle bu iki isim saha araştırmacılarının ilgisini çeker. "Türk, kâfirle yaka paça olandır” diyen Özel de

2 Türkiye'de ikamet edip farklı dinlere mensup olan, yani dini ayrı ama Türklüğü kabul etmiş, Türkleşmeyi özümsemiş; Türk milleti kavramını savunan farklı etnik kökenlerden vatandaşların var olduğunu inkâr etmek mümkün değildir. Mesela Türklere yönelik terörün yoğun olduğu bir dönemde, kendilerini Ermeni kökeniyle tanımlayan terör örgütü Asala'nın, Türk misyon şeflerine yaptığı suikastları ve Türk halkına karşı gerçekleştirdiği vahşi cinayetleri protesto ederek Atatürk anıtı önünde kendini yakan ve Türk milletinin birlik olması gerektiğini savunan Ermeni asıllı Türk Artin Penik, yakın tarihin mühim bir örneği olarak hafizalarda yer etmiştir. Yine mali ve siyasi yönden Türkiye'nin gelişmesine katkı sağlayan, Müslüman olmamasına rağmen ülke dışında iken ezan sesini, yurdunu, milletini özlediğini söyleyen ve başka yerde yaşamak imkânı varken Türkiye'den ayrılmamış Rum, Yahudi kökenli çok kimsenin var olduğunu belirtmek gerekir. Sözgelimi geniş bir Türk - Musevi toplumu olduğunu anlatan ve aynı zamanda bu toplumun liderliğini de üstlenmiş olan Bensiyon Pinto, hatıratında bu doğrultuda hislerini açıklar ve bazı tarihî bilgiler verir. (Bkz: Bensiyon Pinto. (2008). Anlatmasam Olmazd1, Doğan Kitap, İstanbul) 
dini, Türklüğün ön şartı hatta olmazsa olmazı kabul eder. ${ }^{3}$ O, Ömer Seyfettin'den farklı olarak, dini İslam olan her ferdi Türklük dairesinde görür. Şu da belirtilmelidir ki günümüz Türkiye'sinde, farklı milliyetçilik anlayışları (resmî, teritoryal, etnik vs.) bulunur ve aydınlar arasında belirgin bir konsensüs oluşmamıştır. Ömer Seyfettin de bu değerlendirme bağlamında düşünülebilir. Onun ifade ettiklerinin, bugünün millî birlik harcına ve siyasal dengesine katkı sağlayan yanları gözden uzak tutulmamalıdır (Çilliler 2015: 62).

Ömer Seyfettin Türklük bağlamında, vatanı, üç başlık altında ele alır. İlki millî vatandır ve bu "Turan" kelimesiyle simgelenen, Türklerin tarihte bir kez dahi olsa ayak bastı̆̆ı ve bundan dolayı millî vatan olarak telakki edilen her yerdir. İkincisi dinî vatandır ve ezan okunan her İslam beldesi bu kapsamdadır. Sonuncusu egemenliği tasdik olunmuş fiilî vatandır. Sanatçıya göre Türkiye, fiilî vatanımızdir. (325).

Ayrıca sanatçı, millî vatan evladıyla fiilî vatan evladı arasında fark olmadığını söyler. Yukarıda belirtildiği üzere aslında Gagavuz ve Yakut Türklerini Türklük kapsamı dışında bırakmakla birlikte, diğer taraftan, bu ifadesiyle onları da Türkiye Türkleri gibi kabul ettiğini belirtmekte, bu yüzden konuya dair farklı yazılardaki görüşleri bizatihi birbiriyle uyumsuz duruma düşer gibi görünmektedir. Bu hususta sanatçıyı yargılamaksızın şöyle düşünülebilir: Ömer Seyfettin, aklındaki ideal ile o döneminin sosyal ve siyasi tablosu arasında bir çıkış ararken

\footnotetext{
3 Konuya dair fikirlerini dile getirdiği "Kalın Türk" adlı kitabında İsmet Özel, İslâm'ı Türklükle telif ederken 'Dârü'lİslâm' = 'Türk vatanı' şeklinde nitelemede bulunur. Ona göre Müslüman demek, Türk demektir. Ömer Seyfettin ise Türklerin tamamını Müslüman kabul eder. "Türklük ile İslâmlı̆̆ın arasında hiçbir fark yoktur ve olamaz da..." der. "Mektep Çocuklarında Türklük Mefkûresi” başlıklı makalesi, bu konuda net fikirler içerir. O, esaret altındaki Müslümanların başka bir yolla değil; ancak Türklük şuurunun uyanışıyla kurtulacağı iddiasındadır. Makalenin, "Millet ve din muhabbeti" başlıklı ara bölümünde, milliyetle dini bir gördüğünü, aralarında fark olmadığını söyler. Ona göre Türkçe konuşmayan Müslümanlar, Türklerin din kardeşidir. Türklük, din kardeşlerinin imdadına koşmaktır.

İki sanatçı arasında nüanslar ve yakınlıklar vardır. Bu bağlamda İsmet Özel'in din parametresine yaklaşımı mühimdir. O, 'İslâm'ın olmadığı yerde Türk yok' der ve devamında şu sözleri sarf eder: 'Tarih Müslümanlıkla ve Müslümanlıktan kazanılmamış bir Türklüğ̈̈n şahidi değil'. (s. 15) Kimlere Türk denildiğini de şöyle açıklar: 'Yükselme tavrına sadakat gösterilerek erişme ilkelerinin İslam dışında başka hiçbir yerde bulunamayacağını anlayanlara Türk denildi.' (s. 16) $\mathrm{O}$ da tıpkı Ömer Seyfettin gibi Türklüğü ırk kavramıyla bağdaştırmaz: 'Türk deyince akla bir karakter, bir vasıf, bir duruş, bir hayatiyet, bir hayâ, bir haysiyet gelir. Soy, sülale, kavmî taallukat gelmez.' (s. 144) Bu bağlamda Türkçenin de Türklüğe ve Türk vatanına kefil olduğunu; dilin millî varlığın devamında hayati rol üstlendiğini kaydeder. Türkçe üzerine söylediklerinin, Ömer Seyfettin ile aynı doğrultuda olduğu ve aralarında bir asır bulunan iki sanatçının, aynı dil hassasiyetini paylaştığı müşahede edilir. Mamafih İsmet Özel'in, Ömer Seyfettin gibi formüle yakın izahları yoktur ve belli yerlerde kavramları yahut soruları, ucu açık hatta müphem şekilde bırakır. Mesela millet üstüne konuşurken, bir milletin nasıl oluşacağı sorusuna, 'Ben bu formülü biliyor muyum, bu konuda reçetem var mı? Hayır, yok! Çünkü 'Bir millet nasıl olunur?' sorusu bir millet olunurken cevaplanabilir... O yüzden 'Bir millet nasıl olunur?' sorusu bir millet olmaya adım attığımız zaman cevaplandırılabilecek bir şeydir.' der. (s. 53) Müşterek kavramları kullanmış farklı aydınların bakış açıları ve kavramlara yükledikleri manalar, geniş ve mukayeseli araştırmalarla ortaya konursa, bundan sosyal bilimler sahası ve Türk fikir hayatı adına önemli neticeler çıkması kuvvetle muhtemeldir.
} 
zihnen sancılı bir süreç yaşamaktadır. Görüşlerindeki uyuşmazlık da söz konusu süreçle ilgili olarak düşünülebilir. Nitekim onun metinlerinde aydınlanma ve millî bilinç konusunu ele alan bir araştırmada, "Ömer Seyfettin, Türk tarihini, kültürünü ve medeniyetini şimdi'de yeni'lemeyi hedefler.” denerek, sanatçının mevcudun içinden ideali aradığı vurgulanır (Eliuz 2012: 333).

Turan, Ömer Seyfettin'in Türkçülük fikirlerinin nihai noktasıdır. Dilde, dinde, histe ve terbiyede birleşerek, bu birliği siyasi bütünlüğe eriştirmek maksattır. Panslavizm, Pancermenizm, Panelenizm, İtalyanların İrredantizm mefkûreleri ve İngiliz emperyalizmi Ömer Seyfettin'e göre kendi maksadına tarihten verilecek örneklerdir. Örnekler içerik bakımından birbiriyle yakın görünse de sorunludur. Buna rağmen söylediklerinden yola çıarak, Türklerin mefkûresinin ne olmas1 gerektiği, şu tek cümlede özetlenir:

"Asya'da birbirine bitişik olarakyayılmış Türk illerini Osmanlı bayrağının gölgesine toplayarak büyük ve kuvvetli bir ilhanlık teşkil etmektir.” (436).

Teklifini ekonomik ve siyasi olarak rasyonelleştirmek ister. Bunun için Çin ve Hint güzergâhını takip eder. Evvela Anadolu'da on beş milyon, Azerbaycan'da beş, Kafkasya'da sekiz milyon Türk olduğunu varsayar. Buhara'dan Taşkent'e, Karakurum'dan Mançurî çitlerine kadar geniş bir coğrafyanın Türkistan'ı oluşturduğunu ve buralardaki halkın hem Müslüman olduğunu hem de Türkçe konuştuğunu söyler. Volga kıyılarında konuşulan Tatarca'nın da genel edebiyat çalışmaları vasıtasıyla İstanbul lehçesine yaklaşacağını, Sibirya'dan Altay eteklerine ve Pamir'e yetmiş milyonluk nüfusun elli asırlık bir tarihî tecrübeyle aynı potada eriyeceğini tasavvur eder. Elli sene önce Hint yollarının Türklerin elinde olduğunu ve İstanbul - Bağdat arasına çekilecek tren hattı ile Hint - Avrupa yollarının - Süveyş bizde kalmak şartı ile birlikte - yeniden Türklerin eline geçeceğini ümit eden yazar, Çin içlerine kadar uzanmanın zor olmayacağı kanaatindedir.

Planlarında Ukrayna oldukça stratejik bir yer tutar. Rus hegemonyasındaki Ukrayna şayet bağımsızlığını kazanırsa, bundan en çok Türkler yararlanacaktır. Ukrayna'nın bağımsızlığının, kurulacak bir Türk birliği için önemine işaret eden sanatçı, onun Rus nüfuzundan kurtulması hâlinde, Türkî coğrafyalarla arada yabancı unsurun kalmayacağını hesaplar. Gemiyle Hazar üzerinden, demiryolu ile ise Hazar'ın güneyinden Gobi Çölü'ne kadar uzanma emelini açıklar. İstanbul'dan 
kalkan trenler Semerkant'a, Erzurum'dan yola çıkanlar Pekin'e gidecek; Doğu ve Batı arasında meydana getirilecek büyük bir ticari, kültürel, teknik etkileşim vesilesiyle yeni bir Türk medeniyeti inşa edilecektir (439).

Osmanlı'nın türlü mahrumiyetler içinde Birinci Dünya Savaşı’na girdiği günlerde kaleme alınmış bu makale tabiatıyla okuyanları yadırgatır. Turan'daki Rus ve Çinli memurları kovma hayallerini anlatan yazar, mevcut sosyal ve siyasi yapının büyüyeceğini; üstelik söylediklerine inancının tam olduğunu bildirir. Görüşlerine itibar etmeyenlere ise tepki gösterir:

“Ve bir gün - bu mukaddes gün o kadar yakın ki... - Orta Asya, Türkistan ve Cenubî Sibirya, Pamir de bizim siyasî hudutlarımız içine girince Garp Türklerinin hükümeti artık Osmanlılıktan tamamıyla çıkıp hakikî ve büyük bir Türk ve Müslüman hükümeti, bir Turan devleti olacaktır.

Osmanlıların hakanı ve bütün Müslümanların halifesi olan zat bütün arz üzerindeki Türklere hükmettiği vakit, hakanlıktan çıkacak, hakanlar hakanı yani 'ilhan' namını alacaktır.

\section{Ey bu küçük kitabı okuyan!}

Sen ĕger milletinin ne kadar büyük ve kuvvetli olduğunu bilmeyen bir zavallı isen, ĕger millî ve mukaddes mefkûrenin hayat verici nurları senin ruhuna aksetmemişse mutlaka gülecek ve:

- Hakikatten ne uzak bir hayal...

diyeceksin. Fakat emin ol ki yanılıyorsun. İhtimal senin duymadiğın ilahî bir nefes, ürperten ve uyandıran hararetiyle bütün Turan's sarlyor. Hakkın muradl yerine geliyor... Muhitindeki değişikliği, hareketi görmüyor musun? İstersen bu hayat ve halâs alâmetini hayal farz et. Lâkin bütün hakikatlerin evvelâ bir hayal ve tasavvur derecesi geçirdiğini unutma. Ve hatırla ki fiilin meşimesi fikirdir." (440).

Ömer Seyfettin, topluma politik ve kültürel bir hedef sunar. Bu yolda milliyet ve din esaslarının ihmal edilmemesi gerektiğini düşünür. Aksi takdirde hedefe ulaşılamadığı gibi ağır bir bedel de ödenir. Tanzimat sarhoşluğuyla unutulan bu esasların topluma maliyetini hatırlatır. Tanzimat politikacılarının, 
"Türklükte bir dinsizlik kokusu olduğunu" fisıldamalarını ise samimi, gerçekçi bulmaz. Sanatçı, yaşadığı dönem içerisinde, “kan kardeşleri”nin ve ehl-i İslâm'ın nasıl ezildiğini görmüştür. Türklerin millî mefkûresi, kandaşlarını ve dindaşlarını kurtarmaktır. Bu noktada fikirlerinin dinî veçhesi belirginlik kazanır. Dahası, İslâm birliğini terennüm eder. "İttihad-1 İslâm" yoluyla "İslâm beynelmileliyeti" meydana getirmek ve Müslümanları, Hristiyanlara karşı korumak da millî ideallerin kapsamı içindedir. Buradan yola çıkarak aslında Arapların da aynı ideale sahip olduğunu söyler. Açıkça "Türk ve Arap'ın mefkûresi birdir” diye yazar. Türklerin gelişmesi, Arapların lehinedir. Nitekim Türkler kendi milliyetlerini ihya ederken onları dışlamamışlar; Arapçayı resmen kabullenmişler, Arapların eğitimi için okullar açmışlardır. (447). Sanatçı, Arapların, Türklügün gelişmesinden sosyal bakımdan ve tarihî olarak menfaati olduğunu savunur. Türklerin, kurulacak bir İslam birliğinin başında bulunmalarına, Arapların bir itirazının olmayacağı kanaatini taşır. ${ }^{4}$ Hâlbuki tam da bu fikirlerini kaleme aldığı sırada, Arap coğrafyasında Osmanlı'ya ve bilhassa Suriye ve çevresinde, Cemal Paşa'nın Arap milliyetçileriyle çatışmasından dolayı Türklere karşı genel bir tepki söz konusudur. Zaten ardından daha ciddi gelişmeler yaşanacaktır. (Cemal Paşa 2012: 35)

$\mathrm{Bu}$ esnada belirtilmesi gereken, Ömer Seyfettin'in fikrî serüveninde yaşanan değişimdir. Onun yazılarına kronolojik olarak bakıldığında, ilk yazdıklarında milliyetçilik yahut Türkçülük önde değildir. Hatta 2 Ocak 1911 tarihli bir mektubunda, milliyet, kavmiyet kavramlarını eleştirir:

“...arzu-yl tealiyi takdis eden Muhammed'in dini, kendi livâ-yı hakikati altında toplananlar arasinda asla 'kavmiyet' tanımaz. Bin şu kadar seneden beri zalâm-l cehl ile örtülen ve ancak bir zümre-i kalile-i felâsifeye malûm olan İslâmiyet-i hakikiyenin gayesi ittihat ve teali, yani intizam ve terakkidir. Islâmiyet'te muhtelif milliyet, kavmiyet gibi çürük, vahi, sun'ı̂ ve gayr-i insanî esaslar yoktur! Garbin mütefekkirleri bu yalan ve hodbinîye, cehalet ve adem-i vukufa, taassup ve vahşete istinat eden esaslart tahribe çalışırken bizim, esasen

\footnotetext{
4 Ömer Seyfettin bu konuda çok iyimserdir. "Millî Tecrübelerden Çıkarılmış Amelî Siyaset” makalesinde, "Bütün Arapların içinde Türklere ve Türklüğe muhalif ve muarı kalan Amerika'da ve Paris 'te hayatlarını geçirmiş birkaç Suriyeli Hristiyan'dır ki, Araplık namına fuzulî bir milliyet iddia ederek kubbede gürültüler bırakmaya çalışılar. Onlara uyan birkaç Müslüman Arapçağız varsa da pek azdır ve adetleri malûmdur." demesi, bunu ispatlar. Bu yazısında ve diğer makalelerinde, sanatçının konuya ağırlıklı olarak din nokta-i nazarından baktığı, sürekli olarak menfaatlerin çatışmadığını söylediği, Arapların Türklüğe hüsnü kabulle yaklaşacağını varsaydığı gözlemlenir. (Ömer Seyfettin, Bütün Nesirleri, Türk Dil Kurumu Yayınları, s. 449, 2018.)
} 
kendimizde mevcut olmayan bu mevzu ve muzır marazları iktisaba çalışmamız laylk mıdır?" (Ömer Seyfettin 2018: 207).

Bu satırlar Ömer Seyfettin' in düşünce gelişiminin kavranması bakımından gayet önemlidir. Mektubunun devamında ise "kavmiyet ve milliyet" kavramları için "beşeriyetin en muzır ve en gayr-i mantıkî budalalığı" nitelemesinde bulunur (207). Ömer Seyfettin'in o dönemde İslâmiyet'i esas kabul eden ve milliyet kavramını aşağılayan bir tutum takındığı açıktır. Hayatının sonraki dönemlerinde cepheye birden fazla defa gidip, düşman elinde tutsak kaldığı; yine arkadaş çevresinin Türkçülük fikrini destekleyen Şahabettin Süleyman, Mehmet Necip Bey, Ziya Gökalp gibi isimlerden oluştuğu hatırlanırsa, görüşlerinde yaşanan değişimin sebepleri anlaşılır.

Yazılarında dikkat çeken bir diğer husus ise Kürtlerdir. O, Kürtlerin sayıca az olduğundan ve şimdiye dek Türklerden ayrılma isteği bulunmadığından bahseder. Türklerden ayrılmaları hâlinde ise Ruslarla ya da Ermenilerle karışmasının zor olmayacağını bildirir. Oysa bunu Kürtler de arzulamaz. Ömer Seyfettin Türk, Arap ve Kürt unsurlarının din temelinde birleştiğini ve Türklerin millî ideallerinin ise temelde aynı esaslara dayandığı için diğerleri için sorun olmayacağı görüşündedir. Onun bu görüşünün tartışmaya açı olduğu belirtilmelidir. Yeryüzünde 20. yüzyıl başlarında yükselen milliyetçilik fikirleri bilhassa Osmanlı'nın parçalanmasında etkili sebeplerden biri olmuştur. Nitekim bu yolla başta Balkanlar'dan, ardından Arap coğrafyasından yitirilen topraklar çok fazladır. Diğer bazı yerler de eklenmek suretiyle Osmanlı'dan onlarca farklı ülkenin doğduğu, yani büyük bir siyasi kopuşun yaşandığı hatırlanmalıdır. Millî mefkûrenin Osmanlı'daki diğer unsurlarla rabıtası kurulurken, dağılma öncesi konjonktürün göz önünde bulundurulduğu anlaşılmaktadır. Nitekim "Millî Tecrübelerden Çıkarılmış Amelî Siyaset" başlıklı makalesinde, Arap nüfusunun yoğun olduğu Şam, Beyrut, Hicaz, Yemen, Basra'dan; Bağdat'taki mahallelerden, Türklük namına medet umması bunun ispatıdır. Oralardaki kısmi Türklüğü adeta ekseriyete yayma çabası içindedir. Azınlık saydığı Çerkez, Ermeni, Boşnak, Arnavut, Pomak halkının Türk muhabbeti duyduğu ön kabulüyle Türklüğü genişletme, Türk birliğini kurma idealinde olduğu müşahede edilir. $\mathrm{O}$, mezkûr beldelerde, önemli bir Türklük rezervi olduğuna kanidir. Ortadoğu'da ise bunu, kültürel - siyasî bir dinamik ola- 
rak kullanmanın mümkün olacağını anlatır. Bu noktada belirtilmelidir ki İttihat ve Terakki çizgisine yakınlığı bilinen Ömer Seyfettin'in, politik vizyon kapsamında döneminin mahut muktedirlerinden çok büyük bir görüş farkl1llğı yoktur. Nitekim onun hakkında ayrıntılı çalışmalarıyla bilinen Nazım Hikmet Polat da "Ömer Seyfettin siyasi kanaatleri itibariyle İttihat ve Terakkî mensubudur" der ve yazdıklarının bu grupla organik bağlar içeren mahfillerde yayımlandığını; bazı yazılarının açık bir şekilde bu siyasi çizginin propagandasını yaptığını bildirir (Polat, 2007: 80 - 82). Mamafih “Ömer Seyfettin'de Milliyetçilik Düşüncesi” başlıklı makalesinde Olcay Önertoy, Ömer Seyfettin’in faal bir askerken milliyetçi görüşlerinde daha katı ve ısrarcı olduğunu fakat sonrasında tedricen Turancılıktan Türkçülüğe geçtiğini ve makul bir milliyetçi çizgi sürdüğünü söyler. (TTK, 1992: 85).

Ömer Seyfettin'in sürekli vurguladığı husus ideali, iddiası olmayan milletleri yeryüzünde hazin bir sonun beklediğidir. Rumların, Bulgarların, Sırpların millî idealleri, Osmanlı'dan toprak koparmaktır ve Türklerin aleyhinedir. Keza tüm Avrupa aynı emelleri besler. Bunu fark etmemek mümkün değildir:

“Avrupa'nin, yani 'Hristiyan beynelmileliyeti'nin yegâne gayesi ve düşüncesi son İslâm hükümeti olan Türkiye'yi ve Türkleri mahvetmektir. Bunu anlamamak için tamamıyla kör ve duygusuz olmall. 'Tamamiyet-i mülkiye'mizi temin eden Avrupa'nın yalanlarına inanmak, onların nazariyelerine itikat etmek - işte gayet doğru ve serbest söylüyoruz - eşeklikten başka bir şey değildir." (Ömer Seyfettin, 2018: 449).

Avrupa'nın Lehistan'ı nasıl parçaladığını anlatarak, benzer yöntemlerle Osmanlı'ya da aynı oyunu oynadığından dem vurur. Sanatçının anlattıkları şöyle özetlenebilir: Avrupa muhalefeti güçlendirir, ona güçlü söz hürriyeti sağlar. Hükümetin muhalif kanada despotluk sergilemesi, ecnebilerin işine gelir. Kargaşa ve tepki doğar. Avrupa Türklere karşı Ermeni ve Kürt unsurlarını kışkırtır. Anarşiyi perde ardından destekler. Türk iktisadi kaynaklarını yağmalar. Buradaki idaresizliğin sonunu ise ordularıyla getirir. Milletin ve memleketin dağıllışı müş̧erek ideallerin olmayışındandır. Avrupa ideallerinde sebatkârdır. Avrupa'daki her milletin kendi geleceğine yönelik fikirleri, planları varken Türklerin millî ideallere sahip olmaması düşünülemez. Doğu sınırları da başka bir tehlike içinde iken uyanık olmak lazımdır. Rusya da Ermenileri desteklemektedir ve bir muhtariyet 
ile Ermenistan'ın kurulması planları vardır. Bununla beraber azınlıkların kurnazlıklarına dair halkın zihnini aydınlatmak fikri, sanatçının yazdıklarında belirgindir (Şengül 2001: 11). Ömer Seyfettin, kısa süre zarfında elden çıkan Girit'i, Selanik'i, Makedonya'yı örnek vererek, ciddiye alınmayan risk ve tehditlerin bir haftada nasıl hakikat olacağının herkesçe düşünülmesini ister. Ona göre eskiden beri Türklüğü parçalayan iki kuvvet bulunur. İlki Ruslardır. Ondan daha etkili olanın ise millî gaflet olduğunu kaydeder. Hatta ikincisine karşı durmanın farz olduğunu bildirir. (533). Sanatçı, bu konudaki açıklamalarının ardından ağır konuşur:

"Hâsıll, her milletin bir millî mefkûresi vardır. Millî mefkûresi olmayan millet bir hayvan sürüsünden başka bir şey değildir.” (460).

Ardından nasıl bir yol tutulacağını bildirir. "Taarruzî bir mefkûre" inşa edilmelidir. Aksi takdirde Ermeni ve Ruslar Türkleri Kızılırmak’a dökmek, Avrupa dişini etimize geçirmek için beklemektedir. Türk'ün adının tarihten silinmesi için firsat kollayanlar vardır (448 - 449). Evvela herkesle hoş geçinmenin ham hayal olduğunu bilmek lazımdır. "Kanlı hatıralar" unutulmamalıdır. Tanzimat sonrasında millî ruhun zedelenişi ise cemiyet hayatına öldürücü bir darbe indirmiş, ruhlarda büyük hasar meydana getirmiştir. "Taarruzî bir mefkûre" ile millî hayat canlandırılmalıdır. Olanlara bigânelik ve etrafıyla sorunsuz yaşama arzusu, ideal diye sunulamaz; bu, miskinliğin ta kendisidir:

"Buna mefkûre denmez. Miskinlik denir. Milletlerin mefkûreleri daima taarruzîdir. Tedafüî ve korkak düşünceler mefkûre sayılmaz. Bir milletin taarruzî ve millî bir mefkûresi olmazsa o millet korkak ve emelsizdir. Zayıftır. Allah'ın kanunu cezasinı verir. O kanun da:

Ezmeyen ezilir... (Vurgu Ömer Seyfettin'e aittir.)

düsturudur. Başkalarını ezmeyen milletleri diğer milletler ezerler bütün umumî tarih bu kanunun şahidi ve ispatıdır. Başka milletlerden ülke zapt etmek istemeyip kendi hudutları içinde nihayete kadar oturmasını düşünen korkak ve miskin bir millete komşu milletler asla rahat vermezler. Birleşir, üzerine salarlar. Bize yaptıkları gibi, memleketlerini yă̆ma ederler. Hepsini keserler." (464-465).

İfadeler nettir. Yeni ülkeler fethetmek, sınırların genişlemesi onun hedefidir. 
Ömer Seyfettin'in bu fikirlerini bugüne aynen uygulamak mümkün değildir. Belki eski zamanlardaki kudret böyle sağlanmıştır. Günümüzde ise böylesi ifadeler siyasi tehdittir. 21. yüzyılda, uluslararası güç odakları yerel, ulusal ve bölgesel siyasi diskuru düzenli biçimde takip eder. Çağımızda artık resmi beyanatlar veya aydınların paradigmaları bir ülkenin askerî kuvvetinin analiz altında tutulmasına kâfi sebeptir. Yukarıda nakledilenlerin, dağılan bir siyasi yapının içinden acı ve üzüntü ile yankılanan sesler olduğu unutulmamalıdır. Günümüz için ne kadar tehditkâr bir siyasi hava taşıdığı açıktır. Bununla birlikte, bir ülkenin, kendi coğrafyasının insan ve tabii kaynaklarına tam manasıyla hükmedebilmesi, o ülkeyi belli bir düzeye eriştirir. Psikolojik, teknik, kültürel üstünlük merkezi olmak, kendiliğinden etrafı etkiler. Güçlü bir medenî yapı, çevrenin böylesi çekime karşı koyamayacağı doğal politik bir aura oluşturur. "Tedafüî" olmayan ve "taarruzî" cephe taşıyan bir ideali bu şekilde de gerçekleştirmek mümkündür. Ömer Seyfettin'in bir asır öncesinin konjonktürü ve hissiyatıyla şekillenmiş millî idealleri şayet günün reel-politiğinin süzgecinden geçirilirse makul bir senteze ulaşılması güç değildir.

"Ezmeyen ezilir" düsturu, bir yönüyle harcı âlem bir ifadedir. Ömer Seyfettin'in bu ifadeyi kullandığı 1914 tarihli yazısının ardından fikirlerini tavzih ettiği bir başka makalesi daha vardır. Dört sene sonra yayımlanmış "Mürteciler Karşısında Din" başlıklı makalesinde ise görüşlerini emperyalizm kavramını da kullanarak açıklar. Daha evvel ülke sınırlarını genişletmekten ve başka milletleri ezmekten bahseden yazarın, burada, yayılmacılığın yani emperyalizmin kötü olmadığını anlattığı müşahede edilir. ${ }^{5}$ Bir alıntıyla düşündüklerini açıklar ve "Emperyalizm, küçük büyük komşu milletlere tahakküm, her milletin harsını, lisanını, istiklâlini mahvetmek değildir" der. Bu ifade, kötülügüüle bilinen emperyalizmin Ömer Seyfettin tarafından algılanışını aksettirmesi bakımdan mühimdir. O, emperyalizmin Türklüğe hizmet edeceğini düşündüğünden âdeta kavramın anlamını törpüler. Bununla birlikte mezkûr ifadenin ardında yatan görüşlerini daha fazla yazmaz. Şunu söyleyerek devam eder: "Hangi millette bu tabî̀ 'birleşmek, toplaşmak' mefkûresi yoksa yaşamaya layık değildir.”(547).

5 Aslında o, bu konudaki görüşlerini hiç saklamaz. "Antilimilitarizm” başlıklı makalesinde, "Kavileşen, büyüyen milletler zayıflayan, küçülen milletleri yutar, temessül ettirir. Zira zaylf ve marizler kendi başlarına bırakılırsa ölürler, taaffün ederler." diyerek açık şekilde zihnindekileri ifade eder. (Ömer Seyfettin: Bütün Nesirleri, s. 205, Türk Dil Kurumu Yayınları, Ankara, 2018.) 
$\mathrm{O}$, Turancı anlayışı dolayısıyla yayılmacılı̆̆ savunur. Farklı coğrafyalara dağılmış Türkler ayrı devletler hâlindedir. Siyasi hudutlar Türklüğü parçalamıştır. Bir gün Türkler birlik sağlarsa tabiatıyla siyasi coğrafya da değişir. Türklüğün birleşmesi dolayısıyla başka yerler ve milletler de kaçınılmaz şekilde Turan'ın içine dâhil olur. Emperyalizmin tahakküm olmadığını düşünen sanatçı, Turan'a mani olacak hür milletleri, zihninde tereddütsüzce kendi egemenliği altına alır. Belki Osmanlı'nın Araplara tanıdığı, kendi lisanında eğitim gibi bazı hakları, egemenliğine kattıklarına da vermeyi, böylece kültürel bir serbestlik sağlayabileceğini düşünmektedir. Ne var ki her emperyal hedef asimilasyonla noktalanır. Kısacası, ondaki "Emperyalizm, istiklâli mahvetmek değildir" fikriyle Turan ideali, birbiriyle bağdaşmayan hususlardır.

Onun görüşlerini yanlış değerlendirenler bulunmuştur. Bunlardan bir tanesi sanatçı üzerine müstakil bir çalışması olan Necati Mert'e aittir. Mert, Ömer Seyfettin'in görüşlerini tevil ederken Türk birliğini sadece İstanbul Türkçesi ile sınırlı tuttuğunu kaydeder. Konunun ardında yatan siyasi planı görmez. Oysa sanatçının asıl heyecanlandığ kısım ise siyasi bütünlüğe doğru yürüyüştedir. Necati Mert'in değerlendirmesi, Ömer Seyfettin'in görüşlerini yumuşatmaya ve olduğundan başka bir şekilde takdime yöneliktir:

“Ama, Ömer Seyfettin'de Türklük de tarihsel bilinçten, kültürel mirastan fazla bir anlam taşımıyor. Şovenizme varmıyor. Bu durumda din'in de Türklük'ün de uçlarda tutulmayıp birbirilerine yaklaştırıldıklarından söz edilebilir belki. İmparatorluk dışındaki Türkler için de tutumu dengelidir Ömer Seyfettin 'in. Örneğin bu Türklerle kurulacak birliği, Istanbul Türkçesi ile sinırlandirır. Meseleyi siyasileştirmez." (Mert, 2004: 456).

Yukarıdan itibaren Ömer Seyfettin'in konu etrafındaki fikirleri ele alınmıştır. Ondaki Türklük fikrinin neden kaynaklandığı ve kapsamı bellidir. Konuyu Türkçe ile sınırlı tutmadığı da ortadadır. Necati Mert'in, Ömer Seyfettin'in, meseleyi siyasileştirmediğini söylemesi, son derece isabetsiz bir hüküm olmuştur. Bilakis o, savunduğu millî idealleri siyasetle yoğurmuştur.

Peki, Ömer Seyfettin sahip olduğu millî idealleri nasıl gerçekleştirecektir? Hatta ondan önce, ortak düşüncelere, millî ideallere nasıl ulaşılacaktır? 
Ona göre millî idealin oluşması için ilk olarak birliktelik sağlanmalıdır. Birlik, cehaletin aşılmasıyla sağlanır. Türk edebiyatı ve güzel sanatlar önemsenmelidir. Ticaret güç kazanmalıdır ki müreffeh bir Türklüğe giden yol açılsın... Din gibi milliyet de sevilmelidir. Türk tarihi öğrenilmelidir. Destanlarda kalan, ham hâldeki Türk mitolojisi işlenmelidir. Her fert kendinin fani, milliyetinin ve ideallerinin daimi olduğunu bilmelidir. Her Türk, Türkçeyi güzel şekilde konuşup yazmalıdır. En önemlisi dil bilinci meselesidir. Turan ideali, dilde birliği sağlamakla gerçekleşecektir. Bunun için de İstanbul Türkçesi esas alınmalıdır. Aydın bir millet, aydın kadrolar teşekkül edince, geri kalan kısım pratiktir ve tarihin, siyasetin akışıdır.

\section{Türkçe - Dil Bilinci Dilin Sosyal Fonksiyonu}

Ömer Seyfettin'in dil meselesine bakışında pragmatik bir taraf vardır. O, çözülen ve gitgide eriyen bir yapının imarı için önceliğin ne olduğunu düşünür:

"Toptan, tüfekten, ateşten, demirden evvel darülfünun, mektep, muallim, edebiyat, sanat, ilim lazımdı. Bunlarsız ordu, bunlarsız muharebe kat'i bir felaketti. Muhakkak bir hezimetti." (Ömer Seyfettin, 2018: 562).

Sanatçı, modern dünyanın yeni silahlarının ilim, fen, edebiyat ve felsefe olduğunu yazar. Teknik, sanat, felsefe artık hem sömürünün öncü kolları hâlinde kullanılmakta hem de galibiyete giden yolları açmaktadır. Onlarda muvaffak olmak için ise hiç şüphesiz iyi işlenmiş, incelikli bir dil lazımdır. Türkçe, İstanbul Türkçesi bir edebiyat ve ilim dili hâline getirilmelidir. Gençlere, yazarlara bu yolda büyük vazifeler biçer. Kısacası, dilin, sosyo-politik çöküşe deva olacağı ve kurtarıcı fonksiyonelliği olduğu görüşü, onun dile yaklaşımının ilk yanını teşkil eder.

Söz konusu pragmatizmin ikinci yanı ise Türkçülük ile ilgilidir. Turan'a giden yol dilden geçer. Kırım, Başkırt, Kazak bugün ayrı ayrı Türk devleti olsa da ayrı millet değildir. Hepsi dili bir, tek Türk milletidir. Lehçe farkı, lisan farkı ifratına vardırılmıştır. Bu, Rus siyasetidir. Ruslar en ufak farkları dahi abartmış ve kültürce birleşmesini istemediği Türkleri ayrıştırmakta başarılı olmuştur. Millî siyaset gereği Rus propagandası iflas ettirilmelidir. O yüzden Türkler, Türkçede birleşmelidir. Gaspıralı'ının “dilde, fikirde, işte birlik” prensibini hatırlatan Ömer 
Seyfettin, önceliğin Türk dünyasının lisanca birleşmesinde olduğunu savunur. Ömer Seyfettin'de Türklük ve Turan hayali dil paydasında ele alınır. Türkçe, Türklüğün tüm coğrafyalardaki sosyal koordinasyonunu sağlayacaktır. Ortak bir dili kullanamamanın, bir imparatorluğun sonunu getirdiğini, kendi askerlik tecrübeleriyle anlatır. "Balkan Harbi Hatıraları"nda, "Heyhat... Mademki bizde bir ideal, bir vatan hissi, nihayet bir lisan yok... Bölüğ̈̈n yarısından ziyadesi Türkçe bilmiyor. Tabur Babil Kulesi gibi. Ne alanin satandan, ne satanin alandan haberi var." diyerek ordudaki insicamsızlığı ve peşi sıra gelen bozgunu dahi aynı noktaya bağlar. (1026). Bir başka yerde ise "Ve lisan öyle bir vatandır ki bozulursa artık ne millet kalır, ne devlet..." sözleri ile dil konusundaki sabit kanaatini yeniden vurgular. (339). Vatansever olup milliyetine bağll1ık hissedenler, Türkçeye sahip çıkarlar. Türkçe gelecekteki politik aksiyonların kendisinden güç ve hız alacağ1 verimli bir yataktır. Kurumlaşacak birliğin yegâne kurucu unsuru, ortak kültürün ilk kaynă̆ıdır (Aktaş, 2018: 264).

$\mathrm{O}$, yaşadığ zaman diliminde konuşulan ve yazılan dilin birbiriyle uyumsuzluğunu örneklerle anlatır. Türkçenin Arap ve Acem tecvidiyle yoğrulduğundan, cümlelerin lüzumsuz uzadığından; dilin temenna, öksürük ve enfiye kokusu içinde kaldığından şikâyet eder. (Ömer Seyfettin, 2018: 389). Ömer Seyfettin, Türkçenin sıhhatli bir zeminde tartışılmasına ve güzel şekilde yazılıp konuşulmasına en çok katkı sağlayanlardandır. Bir dilin, başka bir dilden kelimeler alsa bile, kaideler alamayacağını ısrarla vurgular. Sanatçı, dile pragmatik yönden bakmanın yanı sıra, dili müstakil bir konu olarak da ele alır. "Yeni Lisan" ve "Güzel Türkçe", "Türk Sarfı ve Şivesine Dair”, "İskolastik Lisanımızın İflâsı”, "İstanbul Türkçesi Hangisidir?” başlıklı seri makaleleri, "Kelimelerin Mânâları Nerededir?”, "Türkçeye Dair”, "Türkçe ve İlim”, "Sağlam Zemin” makaleleri ve muhtelif edebî polemikler bu çerçeve içine alınabilir. Bu yazılarda sanatçının dile teknik açıdan yaklaştığı; gramer, semantik, yazma ve okuma sorunları üstünde durduğu; dilin mevcut problemlerini işlediği görülür. Türkçe söz konusu olduğunda, en yakın arkadaşı sayılan Ali Canip'i dahi eleştirmekten geri durmaz. Kullandığı yabancı kelimeleri "edebî bir günah", "millî bir cinayet" şeklinde nitelemekten imtina etmez (414). Şu görüşlerini aktarmak, Ömer Seyfettin'in dil bilincinin anlaşılması bakımından faydalı olacaktır: 
"Lisan vatan kadar mukaddestir. Fiilî vatanımız olan Türkiye'de, millî vatanımız olan Turan'da nasıl yabancı düşmanlar bulunmasını istemezsek lisanımızda da Türkleşmemiş ecnebi kelimeleri, ecnebi kaideleri istemeyiz. Millî gurura, millî izzetinefse malik olmayan eskiler güzel Türkçemize giren yabancı kelimelerin Türkleşmemesine, ecnebi kaidelerin ecnebi kelimelerle sanki kendi öz yurtlarında imiş gibi hâkimiyetlerine kızmiyorlardl." (405).

Yüzyıl öncesinden bugüne uzanan bu bilincin, zaman içerisinde kök saldığını ve yemişlerini verdiği söylenmelidir. Temiz dil, İstanbul Türkçesi hassasiyeti hiçbir zaman için toplumun genelinin meselesi olmamıştır. Bununla birlikte dile özen gösteren, dilin sosyal fonksiyonlarından haberdar bir kesim daima olagelmiştir. Ömer Seyfettin'in çıkışları ve polemikleri, ardından gelenler için düşündürücü ve yol gösterici bulunmuştur. Onun Yeni Lisan etrafindaki kalem kavgaları, "Cumhuriyet Türkiyesi”"nin aydınları, dil bilimcileri ve edebiyatçıları için ölçü ve entelektüel bir sermaye olmuştur. Türkçeyi, "manevi vatan" olarak telakki etmesi, bir milletin varlığının dil ve edebiyatıyla ortaya konacağını ifade etmesi düşünce, prensip ve ikaz taraflarıyla âdeta bunları ilk yazdığı zamandaki gibi canlılı̆̆ını ve değerini korumaktadır. Ayrıca yeni çağın silahları olan ilim, felsefe ve edebiyatın işlenmiş bir dille elde edileceği fikri de isabetlidir. Türkçenin yerleşik bir ilim dili olması için bir asır öncesinden kulvar açmaya çabalaması takdire değerdir. Bugün hâlâ Türkçenin ilim dili olamayacağını öne sürenlerin varlığı hesaba katılırsa, onun bu konularda ne denli ileri görüşlü ve zemin kurucu bir aydın olduğu anlaşılır. Gerek dil ve milliyet arasındaki ilişkiyi anlatmak gerekse salt Türkçenin önemini ifade etmek bakımından olsun, onun bir uyarıcı olduğu ve ardından gelen nesillere 1şık tuttuğu söylenmelidir. Nitekim onun değerini, “Ömer Seyfettin'in bir öncü olduğu asıl ölümünden sonra anlaşılır. İmparatorluğun can çekiştiği y1llarda bu gerçeği anlamak ve söyleyebilmek güçtür." cümleleri ile belirten İnci Enginün (2004: 292), ayrıca "bütün gençleri de uyanmaya çağır"dığını kaydederek yukarıda dile getirilen tespit ve kanaatleri perçinler.

\section{Diğer Meseleler}

Unutulmamalıdır ki Ömer Seyfettin aslen bir askerdir. Sanatçı bizzat harp ederek devletin parçalanmasını engellemeye uğraşmıştır. Bu yüzden Osmanlı etra- 
fında olan bitenlere karşı duyarlıdır ve yaşanan gelişmelerden kaygılıdır. Fıkra ve makalelerinin hatırı sayılır kısmında, "Haricî düşmanlar kimlerdir ve onlara karşı ne yapılmalıdır?" sorusu ile meşgul olur. Beynelmilelci fikirlerin, özellikle masonluğun yurdun bütünlüğü için zararlı olduğunu söyler. Gizli cemiyetlerin, yabancı ülkelerle münasebetini anlatır. Masonluğa ve bilumum gizli cemiyetlere yurt aleyhinde oldukları için tepki gösterir. Uzak olmadığı İttihat ve Terakki Partisi’nin üyeleri arasında şöhretli masonlar olduğunu bildiği hâlde, Ömer Seyfettin bu gibi beynelmilelci oluşumlardan sakınmış ve onlara muhalefetini de açıkça belli etmiştir. Aynı şekilde "insaniyetçi”" olduğunu iddia eden fikir akımlarına da karşıdır. Onun kaygısı, bu tip fikir akımlarının ve oluşumların, milletin bütünlüğünü sağlayan kıymetlere zarar vermesidir. İnsaniyet, ulusların dostluğu, evrensel insanlık kardeşliği gibi sözlerin altında gizli siyasi saikler olduğuna inanan sanatçı, böyle söylemlerin ardından ordu, vatan, millî duygu ve hasletlerin eleştirisinin geldiğini ifade eder. "Vatan! Yalnız Vatan..." başlıklı makalesinde, zararlı akım ve cemiyetlerin Avrupa ile münasebetine değinerek, bu işin emperyal boyutu olduğuna dikkat çeker:

“Kendi memleketlerinde 'insaniyet've 'beynelmileliyet'fikrine isyan eden bu meş'um cereyanı durdurmaya çalışan ve bir cihetten muvaffak olan Avrupal-lar, bizim memleketimiz için bu vebayı teşvik ederler. Dikkat ediniz, vatanımızda beynelmilel gizli cemiyetler teşkil eden, beynelmilel gizli gayeler takip olunmasını takdir eden hep Avrupalılardır.

Halbuki onların fikirleri sarihtir: Bizi yutmak!.. Evet, bütün Avrupa kavimleri 'emperyalizm' istila gayesini takip ediyorlar. Lakin istilâ ve istimlâkin de şekli değişti. Tarih bu tahavvülü pek vazıh gösteriyor. Eskiden Romalılar bir usul bilirlerdi: Milletleri silahla mağlup etmek, memleketlerini zapt etmek, kuvvetlilerini esir gibi satmak... Bu tarz tamamıla terk olundu. Şimdi bir nüfuz mıntıkası peyda ediliyor. Oradaki ahalinin milliyet fikri uyuşturuluyor, iktisadî ve içtimâ̂ membalar ele geçiriliyor. Istilâ temin olunuyor...

Avrupalılar niçin 'Beynelmileliyet' fikrini memleketlerinde istemiyorlar? Çünkü onun hazırladı̆̆ı akıbeti görüyorlar. Zaten vatan düşmanlı̆̆l, ordu düşmanlığl gibi tezahürler onları yıldırmıştır.” (259).

Haricî düşmanlar, önce, kendilerine bir hedef bölge seçer. Ömer Seyfettin bunu "nüfuz mıntıkası" ibaresiyle anlatır. Bu, coğrafi bir mahal olabileceği gibi 
toplumun özellikle hedef alınmış bir kesimi mesela gençlik de olabilir. Nüfuz mıntıkasında durmadan fikirlerini işleyen ve sözlerini geçirmeye uğraşan düşmanlar, oradan hareketle nüfuzlarını daha geniş bir alana yaymaya çalışır. Böylece kendi ön kabul ve prensiplerini, halkın geneline kanıksatma yoluna giderler. Düşman olmalarına rağmen milletin içinde kendi hükümranlıklarını görünür bir meşruiyete oturtmaya uğraşırlar. Bu yolda hizmet eden "beynelmilelcilik" ve "insaniyetçilik” sureti haktandır. Ömer Seyfettin'in dikkat çektiği aslında bu durumdur ve Türkiye'nin son zamanlarda maruz kaldığ 1 asimetrik konjonktürel tehdit düşünülürse, sanatçının günümüzden bir asır öncesinden bugünün insanına, gençliğine, yöneticilerine ne mesajlar verdiği ortadadır.

Ortak bir tarihin, maneviyatın, milliyetin tenkidi; geçmişle alay edilmesi, gençliğin amaçsızlığa, sefahate sevki, kurumların ciddiyetinin gölgelenmesi, kozmopolitliğin şeref sayılması tehlikelidir. Millî bünyeyi tahrip eden bu eylemlerin, bugün hümanizm ve küreselcilik adı altında yapıldığı su götürmez bir gerçektir. Ömer Seyfettin kendi döneminde aynı planların nasıl işletildiğini fark etmiş bir aydındır. Avrupa'nın silah dahi kullanmadan Osmanlı'dan nereleri, nasıl aldığını yazılarında anlatır. Fransa, Suriye'yi; İngiltere, Irak'1; İtalya, Trablusgarb'1; Avusturya ise Arnavutluk'u hem fiilen hem de siyaseten ana gövdeden koparmıştır. İşte koparılan bu yerler hep önceden tespit edilen nüfuz mıntıkalarıdır. (Ahmad 2007: 48 - 50). Orada eğitim yapmışlar, millî karakteri deforme etmiş̧ler, sonunda arzuladıklarını kuvveden fiile geçirmiş̧lerdir. Nüfuz mıntıkalarında önce renksiz, kimliksiz, hikmetsiz bir kitle oluşturulması tasarlanır. Evrenselci bir öz işlenerek apolitik, genel-geçer amaçlar peşinde olan, üst perdeden ahkâm keserek millî değerleri tenkit eden bir zihniyet dolaşıma sokulur. Doğruluğun ve yanlışlığın ne olduğu konusunda belirginlik meydana getiren konturlar soluklaştırılır, muğlak bir hâle getirilir. Fikrî mücadeleler anlamsızlaş̧ırılır. Ciddiyeti haiz konular karikatürleştirilir. Kültürel ve sosyal alanda büyük bir değersizleşme, ardından millî çöküş yaşanır. Böyle bir alanı, herhangi bir gücün tahakküm altına alması zor değildir. "Ömer Seyfettin bugüne neler söyler?” diye sorulduğunda, verilecek cevaplardan biri de budur. Ömer Seyfettin yurdun her daim karşı karşıya kalabileceği tehlikelere dair insanları uyarır. Makul görünen fikrî akımları, genel çerçevesine bakılarak pek sorgulanmayan oluşumları, halkın içinde sessizce faaliyet gösteren lobileri teşrih masasına yatırır 
ve onların maksatlarının neler olduğunu anlamaya ve topluma göstermeye çalışır. $\mathrm{O}$ yüzden fikirleri ve işaret ettikleri ile bugün de değerlidir. $\mathrm{Bu}$, aynı zamanda, yazdıklarının aktüalitesini korumasının nedenidir.

Sanatçı, insanî öze karşı olmadığını fakat bir söylemin ardına gizlenip de hain maksatlar peşinden gidilip gidilmediğinden emin olunması gerekildiğini söyler:

"Biz gayeleri meçhul gizli ve beynelmilel cemiyetlerin vatan ve milliyet fikrine vuracağl darbeyi defetmek, onların memleketimize hazırladı̆̆ içtinap etmek istiyoruz. Bu 'beynelmilel' cemiyetlerin muzmer gayeleri ne olduğunu bilmiyoruz! Ihtimal ki bizim zannettiğimiz kadar muzır ve mühlik değildir ve ihtimal ki zannettiğimizden daha muzır ve mühliktir! Biz, yalnız aşikâr olarak âleme gösterdikleri 'beynelmileliyet' gayesini bütün mazarratlarıla teşrih ve husule getirdikleri firtınaları tetkik etmeye çalıştık. Ve 'vatan'fikrinin kuvvetini muhafaza için bu gibi muzır tezahürleri ezmeye daima çalı̧̧acağız..." (270).

Yukarıdaki paragraf Ömer Seyfettin'in masonluk dâhil türlü gizli cemiyetlere niye karşı olduğunu açıklar mahiyettedir. Sanatçı bu gibi yapılara daima uyanık olunması gerektiğini düşünür ve hep ihtiyatı elde tutar. Biraderlik, organizasyonel dostluk, evrenselcilik ya da sosyalizm ilkeleriyle vatanî ve millî hasletleri kozmopolitliğe çekmeye çalışanların, bu umdeler etrafında kenetlenen grupların yurdun hayrına olmadığı kanaatindedir. Açıkça, "Bir millet için, bir vatan için manevi hastalikların en müthişi, en korkuncu 'insaniyet've 'beynelmileliyet'fikridir." diyen yazar, onların esaslarını taklit ederek milliyeti, orduyu, vatan kavramını ele almanın mukaddesatı örselemek demek olduğunu düşünür. (270). Müşterek değerleri horlamak tüm toplum için sakıncalıdır.

Onun yurda dair çok önemsediği bir değer ise ordudur. Ordu, Ömer Seyfettin de başlı başına bir mevzudur. "Evvela Ordu", "Antimilitarizm” makalelerinde ordunun bir ülke için ehemmiyetinden bahseder. "Büyük topların namlularına serçe kuşlarının yuva yapacağı” bir günü bekleyenlere, tüm Avrupa'nın düşmanımız olduğunu söyler; Rumeli'den nasıl sürülüp çıkartıldığımızı hatırlatır. Rusya'nın Türklerle tam on bir defa savaştığını, Meşhur Rus Çarı Deli Petro'nun, Türklerin Rumeli'den atılması için vasiyeti olduğunu anlatır. Rusya'nın “Azerbaycan'ı yutmak için” İran'ın alt bölgesini İngilizlere bıraktığını, İtalya'yı da Trablusgarp'ı al- 
ması için teşvik ettiğini; Rusya, İngiltere ve Fransa'nın önce siyasi güç odağı olan hilafet kurumunu kaldırtmayı planladığını, ardından Türkleri mahvetmek için emellerinde anlaştığını bildirir (433 - 434). Ömer Seyfettin bir asker olarak stratejiye önem verir. Millî varlığın, askerin konu edildiği yerlerde kesinlikle romantik değildir. Milletlerin büyümek ve yayılmak temayülünde olduğunu, Rusya'nın ve Orta Avrupa'nın da bu minval üzere hareket ettiğini belirtir. Komşularının, Türklerin topraklarını zapt etme arzusu daimidir. Millî varlığın tehdidi dolayısıyla harp kaçınılmazdır. Üstelik Ömer Seyfettin'e göre "Harp olmazsa milletler tembel ve sefil olurlar." (205). Bir ülkenin ordusunun, o ülkenin büyük bir gücü olduğu kanaatinde olan yazar, modern hayat unsurlarının da ordu vesilesiyle toplumda kabul göreceği fikrini taşır. Buna Japonya örneğini verir. Japonlar modernleşme hamlelerini ve kendilerini dünyaya kabul ettirebilmeyi, güçlü ordulariyla başarmışlardır. Orduya gereken ehemmiyeti vermemenin sonunda, hüsran yaşanacağ 1 endişesindedir.

Sanatçı Japonya örneğini önemser. Onlar, Batı'nın maddi medeniyetini almışlar ancak manevi olarak kendi medeniyetlerini yaşatmışlardır. "Yabancılardan yalnız maddî medeniyet alınır, manevî medeniyet alınmaz" diyen sanatçı, Japonlar gibi yapılması gerektiğini söyler. ${ }^{6}$ Bu görüşler tartışılmalıdır. Medeniyet, belli bir fikrî yapının teknikteki tezahürüdür. Belli davranış kalıplarının, belli bir disiplinin, bakış açısının maddeye tatbikidir. Dolayısıyla zihniyetle teknik arasında kaçınılmaz bir etkileşim bulunur. Batı medeniyetinin kendi özgün dinamiklerinden örülü yekpare bir yapısı vardır. Bir medeniyeti, muhtelif kısımlara ayırarak bir kısmını alıp diğerinin kapsam dışı tutmak, mantık ve sosyolojik realiteler bakımından gözden geçirilebilir.

Ömer Seyfettin toplumun geri kalma nedenlerini Batı'y1 körü körüne taklit, ahlaki bozukluklar ve siyasi hatalar gibi başlıca maddelere bağlar. Bilhassa toplumda yaşanan ahlak bozgunu, onu çok rahatsız eder. Para fikri karşısında şeref, haysiyet ve mertliğin tükenişine hayıflanır. Hele harp zamanlarında yapılan vurgunlar tahammül edilecek gibi değildir. Halkın kötülükler karşısındaki sükûtu,

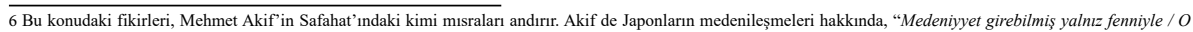
da sahiplerinin lâhik olan izniyle / Dikilip sâhile binlerce basîret, imân; / Ne kadar maskaralık varsa kovmuş kapıdan!" diyerek çağdaşı Ömer Seyfettin'le aynı kanaati paylaşır. Yine Batı'nın maddi medeniyetinin alınması gerektiğini, "Alınız ilmini Garb'ın, alınız san 'atını; / Veriniz hem de mesainize son sür'atini. / Çünkü kâbil değil arțk yaşamak bunlarsız; / Çünkü milliyeti yok san'atın, ilmin; yalnız," mısralarıyla anlatır. Manen millî benliğin müdafaasını ise şöyle dile getirir: "lyi hatırda tutun ettiğim ihtarı demin; / Bütün edvâr-l terakkîyi yartp geçmek için, / Kendi "mahiyyet-i rûhiyye"niz olsun kalavuz. / Çünkü beyhûdedir ümmîd-i selâmet onsuz." Görülüyor ki birbiriyle çağdas olan iki aydın bu hususta hiç de farklı düşünmez. (Mehmet Akif Ersoy: Safahat, s. 170, İstanbul, İnkılâp Kitabevi, 2003.) 
kötüler için soyguna ve yağmaya "rıza alameti" sayılmıştır. O, yurtta bir düzen tesisi için halkın namusu ve adaleti yüksek sesle telkin etmesini ister. Kamuoyu bu konularda susmamalıdır. Aksi takdirde, ahlakı önemsemeyen milletlerin çok geçmeden yıkılacağını sözlerine ekler. Sosyal adaletsizliği ciddi bir mesele olarak görür. Bir hamalın, üniversite hocasından çok kazanması, giderilmesi gereken bir ekonomik tuhaflıktır (810). Sanatçının vurguladığı hususların bugün de karşılığı olan ihtarlar olduğu su götürmez kesinliktedir.

Onun değindiği bir başka önemli konu fikir hürriyetidir. Toplumda egemen olan hoşgörüsüzlük, kendisi gibi düşünmeyeni aşağılamak Ömer Seyfettin'in şikâyet ettiği bir durumdur:

"Kendimiz gibi düşünmeyene hemen:

- Hâin!..

Sıfatını kondururuz. Frenklerin 'tolerans' dedikleri 'müsamahakârlık'-ki medeniyetin, dinin pek büyük amilidir. Bizde habbe kadar yoktur. Adeta bedeviler gibiyiz! 'Fiil' ile 'fikir' sahalarının hududu daha zihnimizde çizilmemiştir. Fikri fiil ile fiili fikir ile karıştırırız... Fikir mesul değildir. Fikir mahkûm edilemez, fikir serbesttir. 'Fiil sahast ise mesuliyet sahasidır.'Bir fikir, fiil sahasina girince karşısında cemiyet kanunlarını bulur fakat biz insanları 'fikir'leri için mahkûm etmeye kalktı̆̆ımızdan tabî̀ bir şey yapamayız. Fiilleriyle cemiyetin kanunlarına çarpacak olan da bu kargaşalıktan istifade eder, arada unutulur...

Fikri için kimseye:

- Hain!

demeye haddimiz yoktur. Iyi fikirlerin, doğru fikirlerin yaşaması için fena fikirlere, yanlış fikirlere ihtiyaç vardır... Hayatta hareketi husûle getiren ancak 'fikrî cereyanlar'dır. Ezelî bir medd ü cezir... Yanlış doğru, iyi fena, muzır faideli fikirler. İşte biz bu sahayı serbest bırakmalıyız. Muzır olmayan fikirler - ĕger korkuları yoksa - rahatça fiil sahasına geçebilirler." (793 - 795).

Ömer Seyfettin bu konuyu fikra ve makalelerinde ele aldığı gibi hikâyelerinde de işler. Murat Koç (2008: 143), sanatçının aslında İttihat ve Terakki’yi merkeze koyup eleştirdiği kanısındadır. Fikir hürriyetine saygı göstermeyip kendilerini mutlak otorite kabul etmeleri hatasına düşmeleri, sanatçının 
yazılarına konu olmuştur. Buradan yola çıkılarak onun yalnızca bir devrin iktidarı özelinde konuştuğunu düşünmek ise Ömer Seyfettin'in görüşlerini kısıtlayan bir bakış açısı olur. 2000'li yılların ilk çeyreğini idrak eden Türkiye'nin, fikir ortamı bakımından bir asır öncesine nispetle ileride olduğunu söylemek makuldür. İfade özgürlüğü, çoğulculuk, demokratik katılım, fikrî zenginlik bakımından Türkiye mesafe kat etmiş bir ülkedir. Yine de onun görüşleri hâlen anlamını korumakta ve dikkate alınması gereken sosyal - demokratik - kültürel prensipler olarak dikkat çekmektedir. Yine yaşadığı sosyal ve edebî ortamı, " Şakayı tahkir, mizahı ciddi, masalı tarih, fanteziyi ilim sanan vatandaşlarımız var!" diyerek tarif ederken, bugünün insanını da uyaran cümleler kaleme aldığını düşündürür (495).

Ömer Seyfettin toplumun kalkınması yolunda kadın, çocuk ve gençlik eğitimine özel bir önem verir. Sporun zihin ve beden terbiyesindeki rolüne değinir. Yazılarında jimnastiğin çokça geçtiği gözlemlenir. Sporda da millî bir taraf olması gerektiğini savunur. Millî jimnastiğin güreş, binicilik, koşu, yüzme, atıcılık olduğunu kaydeder ve bu sporların nasıl yapılacağına kadar ayrıntılar verir. Bir Türk jimnastiğinin geliştirilmesini arzular ki Türklerin sporda özgünlüğe dair neler yapabileceği hakkında muhakeme yürütülmesine katkı sağlar.

\section{Sonuç}

Ömer Seyfettin bir 20. yüzyıl aydınıdır. Yaşadığı dönem fikrî ve siyasi hareketliliğin had safhada olduğu; savaş, yıkım ve acıyla dolu bir zaman dilimidir. $\mathrm{O}$, bir Osmanlı tebaası ve askeri olarak parçalanmanın önüne geçmek için uğraşır. Bunu önlemeye yönelik çeşitli fikir akımlarını inceler ve kendi çözümünü milliyetçilikte bulur. Dini İslâm olup Türkçe konuşan herkesi Türk ilan eder ve Türk paydası altında yürütülecek bir milliyetçiliğin siyasetten spora, edebiyattan ticarete faydalı olacağını yazar.

Aslında yazdıklarına kronolojik bakıldığında, ilkin İslamcılık idealiyle barışık olduğu ancak sonradan milliyetçi görüşleri kendine yakın bulmaya başladığı müşahede edilir. Bu fikirleri ele aldığı fikra ve makaleleri zamanla kültürel bir milliyetçilikten, sınırları aşan siyasi bir ülküye, Turancılığa dönüşür. Ömer Seyfettin'in özünde emperyal bir motivasyon yatan Turancılığı ise Asya'daki bölünmüş ve Güneydeki Arap coğrafyasındaki parçalı hâlde yaşayan Türkleri bir- 
leştirmek emelini güder. Bu dönemde yazdıklarında, Türklerin dört bir tarafının düşmanla dolu olduğu, millî kimliğin derhal idrak edilmesinin önemi anlatılır. Rus, İngiliz ve Fransız tehditleri, Balkan bozgunu, Ermeni ve Kürtlerin Türklere karşı kışkırtılması riski, gizli cemiyetlerin faaliyetleri, muhtelif stratejik fikirler, Anadolu'nun işgal edilme korkusu Ömer Seyfettin'in yazılarında gayet anlaşılabilir kaygılar eşliğinde konu edilir. Zikredilen tüm bu hususların bugün de tehlike arz eden risk, tehdit ve millî endişeler kapsamında ele alınabileceği aşikârdır. Yani Ömer Seyfettin'in fikra ve makalelerinde oldukça geniş yer tutan temalar hâlen aktüalitesini korumaktadır çünkü millî varlığa yönelen tehlikeler ve hissedilen kaygılar aynıdır. Bu da başta jeopolitik konumla izah edilebilir. İkincisi ise aydınların bir asırdan beri ortaya koyduğu stratejik - kültürel fikrî birikimin düzeyi ve hasılası ile alakalıdır. Söz konusu tehdit ve problemlerin bir asırdır aydınlarımızın önünde değişmez gündem maddeleri olması hazindir, düşündürücüdür.

Ömer Seyfettin'in yazılarında, millî kimlik derken kastettiği, Türklüktür. Türklük ise ırk, kan yahut genetik intikali değildir. Dinini ve dilini bilip, terbiye ve karakter formasyonunu Türklerin binlerce yıllık sosyal ve kültürel mirasiyla yoğurmaktır. Öyle olursa, millî benlik oluşur ve her fert, kendinden sonra da yaşayacak olan bir Türk milleti olduğunu, Türklük ideasını kavrar. Varlığını bu yola vakfedecek bir idrake erişir. O zaman millet güçlenir. Güçlenen milletler ise yayılır. Eğer bir ülke, bir millet güçsüzse başkalarının tahakkümüne uğrar. Sanatçının yazılarında orduyu işlediği zaman dilimi işte tam da bu fikirlere sahip olduğu dönemdir. Ülkenin bölündüğünü gören, bir an evvel güçlenerek durumdan kurtulmayı ve etrafa yayılmayı tasarlayan bir irade söz konusudur. Mamafih fikirlerinin Turancılık ideali altında, emperyal bir taraf taşıdığı açıktır. O, Türklüğe hizmeti dokunduktan sonra bunda bir beis görmez. Nitekim istila, fetih devirlerinin hasletidir. Kudret göstergesidir. Oysa Turan idealinin modern dünyanın geçerli siyasi paradigmaları arasına girmesi kolay değildir. Uzun zamandır birbirinden ayrı kalmış; dahası iklimi, ekonomik planları, yaşam ve tüketim tarzları farklılık içeren, siyasi emelleri ve gelecek planları başka olan coğrafyaları ve bu coğrafyaların sakinlerini tek bayrak ya da tek devlet hâline getirmek bugünün sosyo-ekonomik ve kültürel gerçeklerine bakıldığında, oldukça zoraki bir teşebbüstür. Ayrıca tüm dünyada konjonktür değişmiştir. Bilhassa siyasi koşullar 
bir asır önce olduğu gibi değildir. Artık her devletin kendine has öncelikleri, vizyonu, planı vardır ve buna göre hareket edilmektedir. Üstelik Ömer Seyfettin'in söz konusu ettiği coğrafyaların mevcut vaziyetleri, kapasiteleri ve yapabilecekleri işlerin sınırları bellidir. Hepsinin yanı sıra egemenliğini yürüten çok güçlü bir dünya sistemi de hesaba katılmalıdır. Böylesi şartlarda sanatçının Turan tasarısının, gerçekleşmesi mümkün bir ideal olmaktan ziyade, geleceğe dair naif bir siyasi temenni olduğu söylenmelidir.

19. yüzyılın koşullarında din, dil ve coğrafya birliği, Ömer Seyfettin için Türklügün hanesindeki avantajlardır. Bugün ise parçalanmış, birbirinden psikolojik olarak da uzaklaşmış hatta müstakil coğrafyalara ayrılmış ve değişik dinlere mensup olmuş bir Türk nüfus söz konusudur. Türkçe ve İslamiyet, onun savunduğu tezin en önemli istinat noktalarıdır. Hâlbuki hem Turan hayali kurup hem de dini farklı olduğu için Gagavuzların ve Yakutların sanatçının zihnindeki milli şecereden düşmüş olması, bu tezi sakatlar. Oysa özellikle Gagavuzların dil itibariyle Türkiye Türkçesi ile çok yakın oldukları malumdur. Bu da lisan bahsi geçtiğinde, Türkçeyi önemsediğini ve Türkçe üzerinden Türk birliği kurulacağını belirten sanatçının görüşlerinde bir gedik açmaktadır.

O yüzden, Türklük ve millet olma meselesinde, yazarın temel müşterek babından zikrettiği din paydası, muhafazakârca bir yaklaşımla hâlâ geçerli bir önerme gibi takdim edilse de tutarlı bir önerme olarak görünmez. Zaman, gelişmeler ve artık yenilenen modern parametreler göz önüne alındığında, din paydasını, vicdan ya da ideal kavramlarıyla karşılamak daha uygun olabilir. Bugün bakıldığında, milletiyle aynı dini benimsememiş ancak aynı hissiyatı paylaşıp, davranışlarını millî ilke ve yükümlülükler çerçevesinde sergileyen kişilerin varlığından söz edilebilmektedir. Dolayısıyla sanatçının görüşlerinin de bu doğrultuda kritik edilmesi ve toplum lehine revize edilmesi faydalı olacaktır. Aksi takdirde Macaristan'dan Yakutistan'a uzanan coğrafyada, o kadar mitik, kültürel, sembolik müşterek var iken Türklük temelinde bir millî bilinç yakalamak, olduğundan daha da zorlaşacaktır.

Ömer Seyfettin'den İsmet Özel'e uzanan çizgide farklı zaman dilimlerinde; fakat birbirine yakın veya birbirini hatıra getirir şekilde izah edilmeye çalışılmış, Türk ve millet kavramlarının derin ve multidisipliner etütlerle ele alınması, 
ufuk açıcı olabilir. Kavramların izahında tartışmalar doğuran bakış açılarının sosyal, psikolojik, tarihî ve kültürel veçheleri ile yeni bir perspektiften uzmanlar tarafından irdelenmesi, ilmî bakımdan kazanç olacaktır.

Yazarın Türkçe hassasiyeti; dilin, modern çağın silahlarıyla silahlanmak için faydalı bir vasıta olduğu görüşü takdire değerdir. İşlenmiş ve inceliklere sahip bir dilin felsefesi, sanatı, kültürü ile bir milleti ileriye taşıyacağı görüşü son derece doğrudur. $\mathrm{O}$ ayrıca Türkçeyi millî birliğin garantörü olarak görür. Türk birliği için de Türkçeyi mühim bir enstrüman telakki eder.

Sanatçı hem bir asker hem de bir aydın olarak yürütülen politikalara dikkat kesilmiştir. Uğranılan felaketlerin nedenini iyi tahlil etmek lazımdır. Avrupa örnek alınacak bir düşmandır. Siyasetiyle, kurumlarıyla, sinsi emelleriyle ve uzun soluklu planları ile hedefine ilerlemektedir. Ömer Seyfettin, Avrupa'nın "maddi medeniyet” dediği tekniğini önemser. Manevi kısmını bırakıp medeniyetin öylece alınmasını ister. Bu konuda çağdaşı Mehmet Akif'le hemfikirdir. Mamafih bir medeniyeti oluşturan dinamikler girifttir ve felsefesi çalışma disiplinini, mazisi kültürünü, siyaseti tekniğini besler. Dolayısıyla görünen her ne kadar teknoloji olsa da o, bütünün bir kesitidir ve kendini besleyen ekonomik, sosyal, politik diğer unsurlarla ilişkisi vardır. Farklı kaynaklardan gelen yeraltı sularının akıp sonunda birleştiği yer, sadece görünendir. Oysa görüneni oluşturan unsurların meydana getirdiği büyük bir halita söz konusudur. Ömer Seyfettin'in dağılan bir siyasi yapının aydını olarak çözüme hızlıca pratik yoldan ulaşma arzusu ve zamanın aleyhe işlediği fikri, kendisini bu şekilde düşünmeye yöneltmiştir. $\mathrm{O}$, çöken bir sosyal yapının tanığıdır. Batı sancısını, dağılma acısını, yurtsuz kalmayı önlemek, önceliğidir. O yüzden ondan derin tefekkür yerine, fikri derhal pratiğe dökme hamlesi beklemek makuldür.

Ona göre benliğini unutmayan milletler esir de düşseler yaşarlar; sonunda hürriyetlerine kavuşurlar. Yahudiler buna canlı misaldir. Türkler de kendilerini tam manasıyla keşfetmeli, bilmelidir. Esasında ondaki Türkçülük, Turan ideallerinin sebebi bizzat yaşadıklarıdır. Harp görmüş, açlık çekmiş, düşmanla boğuşmuş, esaret dâhil türlü sefaletlere katlanmıştır. Bütün Balkan faciasını görür. Türklerin katledilişine tanık olur. Zorla boşaltılan topraklar, kendi mezarının kazılmasını can çekişirken izleme bahtsızlığına düşen askerler, güçten düşünce yalnız ve ça- 
resiz kalan bir millet onu etkiler. Bulgarlardan can havliyle kaçarken yolda koşa koşa gittiğini üzülerek yazan sanatçının, "Demek Türklerin yaşam hakkı yokmuş" demesi, belki de Türkçülügünün altında yatan en yalın ve temel sebeptir. Kendisine bunu dedirten hadiseleri gözleriyle görmüş, acıyı en derin şekilde hissetmiştir. Yazılarında sulh yerine açık bir şekilde harp taraftarı olmasının da nedenlerinden biri budur.

O, Batı'nın kendi topraklarında istemediği ancak başka ülkelerde örgütlediği aleni ya da gizli oluşumlara karşı müteyakkızdır. Zararlı olduğunu düşündüğü siyasi cereyanlara, biraderlik örgütlenmelerine kamuoyunun dikkatini çeker. Batı'yı tenkit ederken hakkını teslim etmeyi de ihmal etmez. Söz gelimi fikir hürriyeti bağlamında söyledikleri, Batı'nın çözdüğü bir meselenin artık Türklerce de halledilmesi temennisini taşır ve Batı'yı bu bakımdan ileri görür. Sosyal adaletin ve eğitimin ehemmiyetinden bahseder. Millî spor anlayışının geliştirilmesi hakkında ifade ettikleri dikkat çekmektedir. Kısacası, Ömer Seyfettin, kamuoyunun bilinçlenmesine yardımcı olacak görüşlere sahiptir. 21. yüzyılın insanlarına seslenmeyi başarmış bir sanatçıdır. Yazdıklarının hala toplum tarafından okunuyor ve araştırmacılar tarafından inceleniyor olması bunun ispatıdır.

O, ulusal ve küresel ölçekte gelişen olaylar karşısında yön tayin etmede ve sorunların çözümü için çıkış yolu göstermekte hâlen etkili bir kültürel figürdür. Bugünün gençlerinin ve aydınlarının millî bir perspektif çizebilmek için eksiklikleri ya da isabetli görüşleri ile Ömer Seyfettin'in dediklerine eğilmesi, muhakemede bulunması, onun görüşlerini bugüne uyarlamaya çalışması belirli yönleri ile fayda sağlayacaktır. Böylece fikrî mirasın mahiyeti idrak edilecek ve eldeki müktesebat, yarılar için yararlı ve yararsız şeklinde bir seçmeye tabii tutularak verimli bir hâle getirilecektir. 


\section{Kaynakça}

Ahmad, F. (2007). Bir Kimlik Peşinde Türkiye, İstanbul Bilgi Üniversitesi Yayınları, İstanbul.

Aktaş, A. (2018). “Genç Kalemler Sonrası Ömer Seyfettin'in Dil ve Millî Edebiyat Hakkındaki Görüşleri”, Akademik Dil ve Edebiyat Dergisi, 2/3, 253 - 265.

Cemal Paşa (2012). Hatırat, (Haz.: Ahmet Zeki İzgöer) Dün Bugün Yarın Yayınları, İstanbul.

Çalen, M. K. (2015). Kimlik Meselesi Bağlamında Ziya Gökalp Merkezli Bir Ömer Seyfettin Okuması, Türk Dünyası Araştırmaları, S. 215, Nisan 2015, 153 - 166.

Çilliler, Y. (2015). Modern Milliyetçilik Kuramları Açısından 19. Yüzyıl Osmanlı İmparatorluğu Fikir Akımları, Akademik Incelemeler Dergisi, C. 10, S. 2, 2015, 45-65.

Değirmenci, H. Başlangıçtan Günümüze Türk Romanında İstanbul'un Fethi, Yayımlanmamış Doktora Tezi, Marmara Üniversitesi, Türkiyat Araştırmaları Enstitüsü, İstanbul, 2014.

Doğumunun Yüzüncü Yılında Ömer Seyfettin, (1992). Türk Tarih Kurumu Basımevi, Ankara.

Eliuz, Ü. (2012). Ömer Seyfettin Metinlerinde Aydınlanma ve Millî Bilinç, Turkish Studies, $7 / 4,329-336$.

Enginün, İ. (2004). Yeni Türk Edebiyatı Araştırmaları, Dergâh Yayınları, İstanbul.

Ersoy, M. A. (2003). Safahat, İnk1lâp Kitabevi, İstanbul.

Koç, M. (2008). Ömer Seyfettin'in Eserlerinde II. Meşrutiyet ve İttihat ve Terakki, Bilig, S. 47, Güz 2008, 121-146.

Mert, N. (2004). Ömer Seyfettin - İslamc1, Milliyetçi ve Modernist Bir Yazar, Kaknüs Yayınları, İstanbul.

Ömer Seyfettin. (2015). Bütün Hikâyeleri, (Haz. : Nazım Hikmet Polat) Yapı Kredi Yayınları, İstanbul.

Ömer Seyfettin. (2018). Bütün Nesirleri, (Haz. : Nazım Hikmet Polat) Türk Dil Kurumu Yayınları, Ankara.

Özel, İ. (2004). Güncellenmiş Kalın Türk - Günce Ellenmiş Kalın Türk, Tiyo Yayınc1lı, İstanbul.

Pinto, B. (2008). Anlatmasam Olmazdl, Doğan Kitap, İstanbul.

Polat, N. H. (2007). “Ömer Seyfettin” Türkiye Diyanet Vakfi İslâm Ansiklopedisi, 34, 80-82.

Şengül, H. A. (2001). Ömer Seyfettin'de Millî Kimlik, Afyon Kocatepe Üniversitesi Sosyal Bilimler Dergisi, 3/1, 2001, 11-14. 